\title{
Analisis Nilai-nilai Karakter Hasil Karya Menulis Kreatif Siswa
}

\author{
Eka Mufidah Nur Jannah ${ }^{1}$, Heri Suwignyo ${ }^{2}$, Titik Harsiati ${ }^{2}$ \\ ${ }^{1}$ Pendidikan Dasar-Universitas Negeri Malang \\ ${ }^{2}$ Pendidikan Bahasa Indonesia-Universitas Negeri Malang
}

\section{INFO ARTIKEL}

\section{Riwayat Artikel:}

Diterima: 20-01-2019

Disetujui: 12-02-2019

\section{Kata kunci:}

character value; creative writing; reading material; fable story; nilai karakter; menulis kreatif; bahan bacaan; cerita fabel

\author{
Alamat Korespondensi: \\ Eka Mufidah Nur Jannah \\ Pendidikan Dasar \\ Universitas Negeri Malang \\ Jalan Semarang 5 Malang \\ E-mail: ekamufiddah@gmail.com
}

\section{ABSTRAK}

\begin{abstract}
The purpose of this study was to describe the character values in the creativity of students writing fable stories. This study used a descriptive qualitative design with a type of text analysis. The tex analyzed was created by students writing fable stories. The results show of the analysis show five character values in the work of students writing stories. These five values consist of values that are socially caring, friendly/communicative, hard work, creative, and peaceful. Creative writing is telling events that have been experienced by using imagination then poured in the writing. Writing activities require reading skills. The reading used is the story of fables. Fable stories contain moral values in life that can add student knowledge.
\end{abstract}

\begin{abstract}
Abstrak: Tujuan penelitian ini adalah mendeskripsikan nilai-nilai karakter dalam hasil cipta siswa menulis cerita fabel. Penelitian ini menggunakan rancangan deskriptif kualitatif dengan jenis analisis teks. Teks yang dianalisis adalah hasil karya siswa menulis cerita fabel. Hasil analisis menunjukkan lima nilai karakter dalam karya siswa menulis cerita. Lima nilai tersebut, meliputi nilai peduli sosial, bersahabat/komunikatif, kerja keras, kreatif, dan cinta damai. Menulis kreatif adalah menceritakan peristiwa yang pernah dialami dengan memanfaatkan imajinasi kemudian dituangkan dalam sebuah tulisan. Kegiatan menulis membutuhkan keterampilan membaca. Bacaan yang digunakan adalah cerita fabel. Cerita fabel memuat nilai-nilai moral dalam kehidupan yang dapat menambahkan pengetahuan siswa.
\end{abstract}

Pembelajaran dengan menekankan pendidikan karakter menjadi inovasi di pembelajaran abad 21. Penerapan nilai-nilai pancasila yang tertuang dalam pasal 3 sebagai bukti upaya membentuk sebuah framework pembelajaran abad 21. Framework pembelajaran abad 21 yang sudah dijelaskan secara rinci berupa enam keterampilan yang meliputi (a) kemampuan berpikir kritis dan memecahkan masalah, (b) mampu berkomunikasi dan berkolaborasi secara efektif, (c) kemampuan dalam menciptakan dan menghasilkan suatu terobosan yang inovatif, (d) mampu memanfaatkan teknologi informasi dan berkomunikasi dengan baik, (e) mampu mengembangkan diri secara mandiri, serta (f) mampu memahami dan menggunakan berbagai media komunikasi (Badan Standar Nasional, 2010). Keterkaitan framework pembelajaran abad 21 dengan PPK (Penguatan Pendidikan Karakter) yakni, nilai karakter mandiri sesuai dengan poin (e), nilai kreativitas sesuai dengan keterampilan poin (c), nilai demokratis dan peduli sosial memiliki keterkaitan dengan keterampilan poin (b), keterampilan poin (a) sesuai dengan nilai rasa ingin tahu dan bekerja keras, dan terakhir poin (d) dan (f) yang memiliki keterkaitan dengan nilai karakter komunikatif. Hal ini membuktikan bahwa ada upaya dalam mencapai pendidikan yang lebih baik dan lebih maju agar tidak tergerus oleh pesatnya globalisasi.

Penguatan Pendidikan Karakter diaplikasikan di kelas dalam sebuah mata pelajaran dan program literasi. Hal ini dilakukan karena nilai karakter akan dipraktikkan terus menerus oleh siswa. Sifat yang dikenal dan dilakukan terus menerus oleh siswa akan menjadi sebuah karakter, dijelaskan oleh Anderson \& Krathwhol (dalam Rehusisma, Indriwati, Suarsini, 2017) mengenai tingkatan dalam ranah afektif. Tingkatan ini dimulai dari tingkat rendah hingga tingkat yang lebih kompleks yang terdiri atas, tingkat pembiasaan, jawaban, penilaian, mengorganisasi, dan karakter. Tingkat karakter inilah yang diharapkan dapat dibentuk dalam diri anak bangsa. Jiwa yang berkarakter menjadikan keberhasilan pendidikan dalam mencetak generasi bangsa karena tertuang dalam UU. No. 20 Tahun 2003 pasal 3 mengenai tujuan pendidikan di Indonesia adalah mewujudkan pembelajaran dengan mengedepankan pembentukan karakter. Pendidikan karakter menjadi upaya dalam mempengaruhi perkembangan sifat dan kualitas individu yang diharapkan (Hoge, 2002). 
Upaya mendukung pembelajaran abad 21 yang menekankan pendidikan karakter dalam pembelajaran bahasa Indonesia adalah dengan diberikan kompetensi menulis kreatif bagi siswa. Kompetensi menulis merupakan contoh bentuk program literasi yang telah diaplikasikan di sekolah. Tujuan diberikan kompetensi menulis karena keterampilan menulis mengasah daya imajinasi dan mengonstruksi pengalaman sehari-hari siswa, ke dalam produksi kata, kalimat, serta paragraf. Kemudian satuan paragraf tersebut menjadi suatu bacaan yang menarik, khas, dan orisinal karya siswa. Tujuan lain dari menulis cerita dijelaskan oleh (Kette, Pratiwi, \& Sunoto, 2016) bahwa dengan keterampilan menulis kemampuan berbahasa, kepribadian seseorang, cara bersosial, dapat berkembang dengan bercerita, sehingga dengan menulis cerita menjadi lahan dalam membina dan mengembangkan karakter dan kepribadian seseorang. Penjelasan ini dibuktikan betapa pentingnya keterampilan menulis cerita oleh (Nielsen, 2003) bahwa ada tuju metode pembelajaran yang mendukung kemunculan imajinasi dan pemikiran kreatif, salah satu metode belajar tersebut adalah dengan bercerita. Maka, dapat disimpulkan bahwa keterampilan menulis kreatif menjadi pendukung dalam menanamkan pendidikan karakter bagi siswa. Karya sastra berupa cerita menyatakan nilai-nilai karakter tidak dilakukan secara langsung tetapi dengan metafora-metafora cerita sehingga proses pembelajaran dapat berlangsung lebih menyenangkan (Noor, 2011).

Hasil karya tulis cerita siswa apakah benar-benar memberikan gambaran nilai-nilai karakter yang telah diajarkan. Pendidikan karakter yang sudah dikemas dalam materi menulis cerita harapannya mengintegrasikan nilai-nilai karakter dalam setiap proses pembelajaran. Tujuannya tidak hanya menjadikan siswa menguasai kompetensi keterampilan menulis tetapi juga menyadari, mengenal serta dapat menginternalisasi nilai-nilai karakter (Asriani, Sa'dijah, Akbar, 2017). Kegiatan awal yang dilakukan siswa sebelum memproduksi tulisannya yakni melakukan kegiatan membaca jenis-jenis bacaan yang sarat akan nilainilai moral. Melalui kegiatan literasi moral akan memunculkan kemampuan reseptif dalam memahami bacaan, menemukan ajaran moral yang ditafsirkan berdasar pada pengetahuan dan ditampung kemudian dituangkan dalam ide-ide tulisan dalam kegiatan produktif menulis (Wachidah, Suwignyo, \& Widiati, 2017).

Nilai-nilai karakter yang muncul dari tulisan siswa diperlihatkan dengan menceritakan karakter tokoh dalam menyelesaikan konfliknya dan juga alur cerita. Dijelaskan oleh (Nurgiyantoro, 2010b) mengenai pesan moral yang disampaikan dalam cerita tidak hanya terdapat dalam karakteristik tokoh tetapi juga alur cerita yang menjadi gagasan abstrak berkaitan dengan persoalan kehidupan manusia. Melalui kegiatan memproduksi cerita dengan memunculkan nilai-nilai karakter terdapat proses penggabungan antara pengalaman siswa dalam kesehariannya dengan proses membaca. Proses ini merupakan basis menulis kreatif yang dilakukan siswa dengan dibutuhkan pengintegrasian antara ide baru yang telah masuk dengan pengalaman yang sudah tertanam dalam kognisi anak dijelaskan oleh piaget (dalam Rahayu, 2016).

Maka dari pembahasan sebelumnya, penelitian ini akan menganalisis nilai-nilai karakter yang termuat dari karya tulis kreatif siswa. Mengingat ada penelitian serupa yang dilakukan oleh (Wachidah, Suwignyo, \& Widiati, 2017) dengan menganalisis potensi karakter tokoh dalam cerita rakyat. Persamaannya dengan penelitian ini adalah melakukan kegiatan analisis isi cerita dari segi nilainya, tetapi perbedaannya terletak pada aspek potensi karakter tokoh dan bahan bacaannya. Selain penelitian tersebut, penelitian yang juga menganalisis muatan nilai-nilai karakter adalah penelitian oleh (Ridwan \& Mudiono, 2017) perbedaan penelitian terletak pada sumber yang dianalisis, penelitian tersebut menganalisis buku siswa sedangkan, penelitian ini menganalisis karya cerita siswa. Hasil karya cerita siswa yang dianalisis dalam penelitian ini berasal dari proses menulis kreatif siswa dengan menggunakan bahan ajar menulis kreatif. Tujuan melakukan penelitian ini adalah karena banyaknya penelitian yang mengangkat tema nilai karakter seperti penelitian analisis nilai estetik dari sebuah novel yang dilakukan oleh (Wulananda, Saryono, \& Suwignyo, 2016). Selain itu, penelitian yang mengembangkan bahan ajar berbasis pendidikan karakter (Asriani, Sa'dijah, Akbar, 2017) dan pengembangan mulitimedia untuk membentuk karakter anak (Kusmayadi, Suyitno, \& Maryaeni, 2017), sedangkan, dampak dari pemberian bahan ajar, media, dan bahan bacaan novel pada karya cerita siswa belum diteliti. Maka, fokus penelitian ini adalah untuk menganalisis nilai-nilai karakter pada karya cerita siswa, setelah siswa melewati materi proses menulis kreatif menggunakan bahan ajar. Kemudian yang dianalisis dalam cerita siswa berasal dari kutipan prolog, dialog, monolog atau epilog yang merepresentasikan nilai-nilai karakter tersebut.

\section{METODE}

Penelitian ini adalah penelitian kualitatif. Penelitian kualitatif dengan jenis penelitiannya adalah menganalisis teks. Kajian yang digunakan dalam penelitian ini adalah hermeneutika karena penelitiannya bertujuan menafsirkan sebuah teks dan memaknainya. Peran peneliti dalam penelitian ini adalah berperan dalam merencanakan, melaksanakan, mengumpulkan data, menganalisis, menafsirkan data, dan pada akhirnya melaporkan data penelitiannya (Moleong, 2016). Data yang digunakan dalam penelitian ini adalah data non verbal mengenai data yang diambil dari deskripsi kejadian cerita dan deskripsi nilai-nilai karakter dalam cerita. Instrumen pendukung yang digunakan adalah tabel pengumpul dan pengolah data. Sumber data dari penelitian ini adalah hasil karya tulis cerita fabel kelas V SDN Percobaan 2 Malang. Alasan memilih sumber tulisan karya siswa karena ingin mengetahui apakah ada internalisasi nilai-nilai karakter saat pengajaran menulis kreatif dengan hasil karya menulis cerita karya siswa. Hasil cerita yang berhasil terkumpulkan ada lima cerita. Alasan hanya lima cerita yang terpilih karena kelima cerita memiliki nilai-nilai karakter yang berbeda antara satu sama lain. 
Data dikumpulkan dengan teknik dokumentasi karena hasil cerita siswa yang terkumpul berupa lembaran kertas. Teknik pengumpulan datanya dengan membaca hasil karya tulis cerita fabel siswa. Setelah proses membaca dilanjutkan dengan mencatatnya dan memberi kode paparan yang berhubungan dengan fokus penelitian yakni deskripsi kejadian cerita dan deskripsi nilai-nilai karakter, serta mengklasifikasikan data yang sesuai dengan fokus penelitian.

Tahapan penelitian meliputi tiga langkah yakni persiapan, pelaksanaan, dan pengolahan. Persiapannya adalah proses menghimpun informasi mengenai cakupan nilai-nilai karakter dalam cerita anak dan mengetahui nilai-nilai karakter yang ada dalam Penguatan Pendidikan Karakter. Pelaksanaannya mengumpulkan hasil karya tulisan siswa berupa cerita fabel. Tahap pengolahannya adalah mendeskripsikan dan mengklasifikasikan karya cerita siswa termasuk dalam kategori nilai-nilai karakter yang seperti apa dan diolah kemudian dibahas hasil analisis data.

Keabsahan data dicek melalui empat cara terdiri atas (1) keikutsertaan peneliti, (2) ketekunan mengamati, (3) triangulasi data, dan (4) diskusi dengan rekan sejawat. Penelitian ini juga dibantu dengan adanya instrumen pemandu dalam pengumpulan data. Hal ini dilakukan untuk memudahkan dalam menganalisis isi cerita dan cara yang efektif saat setelah menganalisis kemudian ditulis dalam tabel spesifikasi data. Hal yang pertama dilakukan oleh peneliti adalah menelaah teks hasil karya tulisan siswa kelas V SDN Percobaan 2 Malang. Teks merupakan data primer dalam penelitian ini. Kemudian kondisi ini digunakan untuk meneliti apakan hasil karya cerita siswa terkandung nilai-nilai karakter.

\section{HASIL}

Berdasarkan hasil penelitian analisis isi yang dilakukan peneliti terhadap data sumber berupa hasil tulisan cerita fabel siswa. Peneliti mendapatkan lima karya tulis cerita siswa yang berjudul (1) Pinguin si Pembohong (2) Tikus Menolong Raja Rimba (3) Kerakusan Si Monyet, (4) Serigala Jahat, dan (5) Jebakan Kancil dan Kura-kura. Berikut hasil analisis karya tulis cerita siswa pada Tabel 1 .

Tabel 1. Nilai-nilai Karakter Pada Karya Cerita Siswa

\begin{tabular}{|c|c|c|c|}
\hline Judul Cerita & Kejadian Peristiwa & $\begin{array}{l}\text { Nilai-nilai } \\
\text { Karakter }\end{array}$ & Kode \\
\hline Pinguin $\mathrm{Si}$ & "Aduh sakit". Kata Pinguin pink sekali lagi. "Pinguin" teriak teman-temannya. & Peduli Sosial & NK/KCS/02/PS \\
\hline Pembohong & $\begin{array}{l}\text { "Kamu baik-baik saja, apakah ada yang terluka?" kata Naga penasaran. "aku tadi saat } \\
\text { mengambil bola terjatuh dan kakiku terkilir" kata Pinguin. "Sini aku bantu sampai } \\
\text { kerumahmu" kata Naga. }\end{array}$ & Kerja Keras & $\mathrm{NK} / \mathrm{KCS} / 02 / \mathrm{KK}$ \\
\hline Tikus & Tikus menggigit jaring itu, akhirnya jaring memiliki lubang yang sangat besar. & & \\
\hline $\begin{array}{l}\text { Menolong Raja } \\
\text { Rimba }\end{array}$ & $\begin{array}{l}\text { Harimau terbebas dari jaring. "terimakasih Tikus" kata harimau senang. "sama-sama } \\
\text { raja harimau" kata Tikus. "aku akan memberi hadiah kepadamu" kata Harimau. "Apa } \\
\text { hadiahnya raja rimba?" kata Tikus senang. }\end{array}$ & $\begin{array}{l}\text { Bersahabat/ } \\
\text { komunikatif }\end{array}$ & $\mathrm{NK} / \mathrm{KCS} / 02 / \mathrm{BB}$ \\
\hline Kerakusan Si & Merekapun memakan bekal yang dibawakan oleh ibu Rusa bersama-sama. & & \\
\hline Monyet & $\begin{array}{l}\text { "Hmmm... enak sekali masakan ibumu rusa", kata burung perkutut memuji masakan } \\
\text { ibu rusa yang sangat enak, "Terimakasih ya perkutut atas pujiannya" jawab si Rusa } \\
\text { dengan hati yang berbunga-bunga. }\end{array}$ & Cinta Damai & $\mathrm{NK} / \mathrm{KCS} / 02 / \mathrm{CD}$ \\
\hline Serigala Jahat & $\begin{array}{l}\text { Serigala dibantu kura-kura untuk kabur dari cengkraman harimau. Kura-kura berkata } \\
\text { ke harimau "harimau lepaskanlah serigala" harimau langsung melepaskan serigala } \\
\text { dari cengkramannya. Setelah itu serigala terus berteman dengan kura-kura, musang } \\
\text { dan harimau. Mereka tidak lagi saling bertengkar dan tidak pernah mengejek. Mereka } \\
\text { bersahabat dan saling menghormati. Mereka hidup tentram aman dan damai. }\end{array}$ & & \\
\hline $\begin{array}{l}\text { Jebakan Kancil } \\
\text { dan Kura-kura }\end{array}$ & $\begin{array}{l}\text { "Kera apakah kamu mencuri buah-buahan kami?" tanya kancil. "e.. tidak kancil" } \\
\text { jawab kera sambil ragu. Kancil dan kura-kura membuat jebakan untuk mengetahui } \\
\text { siapa pencuri yang telah memakan semua buah milik kancil dan kura-kura. Keesokan } \\
\text { harinya Kancil dan kura-kura melihat kera terjebak dijebakan kancil dan kura-kura } \\
\text { yang sudah dipasang di dekat sungai. }\end{array}$ & Kreatif & $\mathrm{NK} / \mathrm{KCS} / 02 / \mathrm{KT}$ \\
\hline
\end{tabular}

\section{Nilai-nilai Karakter}

Nilai-nilai karakter yang diangkat pada penelitian ini adalah nilai karakter yang dicanangkan pemerintah dalam bidang pendidikan yaitu PPK (Penguatan Pendidikan Karakter). PPK adalah gerakan pendidikan yang dinaungi pemerintah di bawah taanggung jawab satuan pendidikan bertujuan memperkuat karakter peserta didik melalui olah hati, rasa, pikiran, dan olah raga. PPK sendiri bekerjasama antara satuan pendidikan, keluarga, dan masyarakat untuk mewujudkan lingkungan sosian yang berkarakter pancasila. Nilai-nilai dalam PPK juga merupakan penerapan dari nilai-nilai pancasila. Pengertian nilai karakter sendiri secara terminologi nilai adalah sifat yang melekat pada objek itu sendiri (Kaelan, 2008), sedangkan karakter adalah 
mengaplikasikan nilai-nilai kebaikan dalam suatu tindakan atau perilaku (Fathurrohman, 2013). Kesimpulannya nilai karakter adalah sifat yang ada diri seseorang terwujud pada tindakan dan perilakunya.

Nilai-nilai PPK yang diaplikasikan dalam pembelajaran sekolah merupakan penerapan nilai-nilai pancasila. Nilai-nilai pendidikan karakter yang dicanangkan PPK terdiri atas nilai religius, jujur, toleran, disiplin, bekerja keras, kreatif, mandiri, demokratis, semangat kebangsaan, rasa ingin tahu, cinta tanah air, menghargai prestasi, komunikatif/bersahabat, cinta damai, gemar membaca, peduli sosial, peduli lingkungan, dan bertanggung jawab. Hasil cerita fabel buatan siswa yang terkumpul memiliki lima nilai karakter yakni peduli sosial, kerja keras, bersahabat, cinta damai, dan kreatif. Nilai-nilai karakter tersebut muncul secara tersirat dalam cerita buatan siswa. Cerita fabel hasil karya siswa sangat dekat dengan kejadian sehari-hari contohnya nilai persahabatan, peduli sosial, dan cinta damai. Berikut penjelasan muatan nilai-nilai karakter yang ada dalam cerita buatan siswa.

\section{Peduli Sosial}

Pada cerita Pinguin Si Pembohong karya Nasywaa Yulisa siswa kelas V SDN Percobaan 2 Malang ini menceritakan sebuah kisah seorang Pinguin yang bewarna pink sedang bermain dengan rubah dan terjatuh saat bermain. Naga yang diceritakan menjadi hewan yang baik dan suka menolong temannya mendekati Pinguin yang terjatuh diikuti dengan temantemannya. Naga yang sangat baik akhirnya membantu Pinguin untuk pulang dan merawat Pinguin yang tidak dapat berjalan. Tetapi, kebaikan Naga dibalas oleh Pinguin dengan kebohongan dengan masih berpura-pura sakit. Sepintar-pintarnya bangkai ditutupi baunya tetap tercium juga. Cerita tersebut sebenarnya juga mengandung unsur kejujuran tetapi, sosok Naga yang menjadi poin utama yang berlaku baik kepada temannya, bersedia menolong dan merawat, serta masih bersedia memafkan Pinguin. Nilai ini terlihat dari perkataan Naga yang ingin membantu Pinguin Pink.

\footnotetext{
"Aduh sakit". Kata Pinguin pink sekali lagi. "Pinguin" teriak teman-temannya. "Kamu baik-baik saja, apakah ada yang terluka?" kata Naga penasaran. "aku tadi saat mengambil bola terjatuh dan kakiku terkilir" kata Pinguin. "Sini aku bantu sampai kerumahmu" kata Naga.
}

Sikap-sikap itulah yang sebenarnya inti yang ingin diceritakan. Sikap-sikap tersebut juga merupakan aplikasi dari nilainilai peduli sosial. Nilai peduli sosial menurut terminologi merupakan sikap yang ingin menolong/membantu orang lain atau masyarakat yang membutuhkan pertolongan (Narwanti, 2012). Maka sepatutnya manusia sebagai makhluk sosial saling tolong dalam pemenuhan kehidupan sehari-harinya.

\section{Kerja Keras}

Cerita tikus yang menolong raja rimba yaitu harimau. Harimau yang terjebak oleh perangkap pemburu dengan terlilit oleh jaring. Harimau yang putus asa akhirnya bertemu dengan seekor tikus. Tiku yang diperintahkan rajanya untuk membuka jaring yang kuat itu, akhirnya dengan sekuat tenaga menggigit jaring tersebut sampai akhirnya membentuk lubang yang sangat besar. Akhirnya sang Raja Rimba terbebas dari perangkap pemburu, sebagai tanda terima kasih mendapat hadiah dari sang raja. Sikap tikus yang diceritakan oleh Fadhil Akiaz menunjukkan sikap kerja keras yang membuahkan hasil. Tikus yang tidak mengeluh berusaha dengan sekuat tenaga menggigit jaring yang lebar dan kuat itu dengan giginya yang sangat kecil. Hal itu yang menggambarkan nilai kerja keras dalam cerita yang berjudul raja rimba. Berikut cuplikan cerita karya Fadhil Akiaz.

\footnotetext{
Tikus menggigit jaring itu, akhirnya jaring memiliki lubang yang sangat besar. Harimau terbebas dari jaring. "terimakasih Tikus" kata harimau senang. "sama-sama raja harimau" kata Tikus. "aku akan memberi hadiah kepadamu” kata Harimau. “Apa hadiahnya raja rimba?” kata Tikus senang.
}

Kerja keras merupakan perilaku dalam diri seseorang dengan penuh semangat dan motivasi mewujudkan sesuatu yang ingin dicapai dengan berusaha melakukan hal-hal yang kecil sampai hal-hal yang besar. Kerja keras merupakan sikap yang wajib dimiliki semua orang, karena kewajiban semua orang dalam meraih kesuksesan atau meraih cita-citanya harus dengan kerja keras. Sesuai yang dikatakan oleh (Erlfindri, 2012) bahwa karakter kerja keras adalah sifat seseorang yang tidak mudah berputus asa dan memiliki kemauan keras dalam mewujudkan apa yang dicita-citakan. Jadi karakter kerja keras menjadi karakter yang harus dikembangkan dalam dunia pendidikan untuk mencetak anak bangsa yang tahan mental dengan sikap kerja kerasnya.

\section{Bersahabat/Komunikatif}

Cerita yang berjudul Kerakusan Si Monyet karya Nur Ashfi adalah cerita persahabatan kelinci, kijang, marmut, burung perkutut, dan Monyet. Monyet adalah hewan yang terkenal sangat rakus diantara mereka. Monyet ingin memakan mangga, tetapi teman-temannya mengingatkan untuk tidak mengambilnya karena itu milik raja hutan. Monyet terjatuh dari pohon mangga dan teman-temannya menolong. Akhirnya Rusa mengajak teman-temannya makan bersama agar rasa lapar monyet juga hilang. Mereka bercengkerama dan tertawa bersama. Kisah tersebut menunjukkan sebuah komunikasi yang terbangun antar sahabat, mereka saling mengingatkan dan berbagi bersama. Saling bercengkrama, memuji, memberi penilaian, mengingatkan 
merupakan bentuk komunikasi antar teman. Cerita ini memperlihatkan bentuk komunikasi yang dibangun antar persahabatan. Berikut cuplikan yang memperlihatkan komunikasi tersebut.

Merekapun memakan bekal yang dibawakan oleh ibu Rusa bersama-sama. "Hmmm... enak sekali masakan ibumu rusa", kata burung perkutut memuji masakan ibu rusa yang sangat enak, "Terimakasih ya perkutut atas pujiannya" jawab si Rusa dengan hati yang berbunga-bunga.

Penjelasan arti dari karakter bersahabat/komunikatif adalah sikap atau perilaku terbuka pada orang lain dengan menggunakan komunikasi yang santun sehingga terwujudnya kerja sama secara kolaboratif (Suyadi, 2013). Persahabatan sama halnya membangun komunikasi antar sesama, menimbulkan komunikasi yang damai, serta saling toleran terhadap perbedaan. Cerita tersebut menunjukkan cara menyelesaikan konflik dengan sejuk. Monyet yang marah karena kelaparan akhirnya luluh dengan kebaikan rusa yang telah memberikan makanan dan juga teman-temannya yang selalu mengingatkan.

\section{Cinta Damai}

Cerita karya Mohammad Nabil ini menceritakan persahabatan kura-kura dan harimau. Serigala dengan sikap sombongnya mengganggu kura-kura dan mengejeknya. Mendengar ejekan serigala, harimau ingin memberi pelajaran kepada serigala dengan menakuti akan memakannya. Serigala berhasil diterkam harimau dan akan dimakan, tatapi aksi harimau gagal karena kura-kura yang melarangnya untuk memakan serigala. Harimau melepaskan serigala dan menasehati untuk saling menghormati dan tidak saling bertengkar. Kemudian akhir cerita serigala berteman dengan harimau dan kura-kura. Cinta damai adalah bentuk kerukunan bersama, menjaga komunikasi yang sejuk. Komunikasi yang sejuk diwujudkan dengan percakapan yang membangun, bermanfaat, dan mengandung kepentingan bersama. Berikut cuplikan dalam cerita yang menggambarkan cinta damai.

Serigala dibantu kura-kura untuk kabur dari cengkraman harimau. Kura-kura berkata ke harimau "harimau lepaskanlah serigala" harimau langsung melepaskan serigala dari cengkramannya. Setelah itu serigala terus berteman dengan kura-kura, musang dan harimau. Mereka tidak lagi saling bertengkar dan tidak pernah mengejek. Mereka bersahabat dan saling menghormati. Mereka hidup tentram aman dan damai.

Cinta damai adalah bentuk memaafkan kesalahan orang lain. Jika saling memaafkan tidak akan terjadi permusuhan, serta mewujudkan perkataan dan tindakan yang baik. Cinta damai jika diartikan adalah sikap, perbuatan, dan perkataan yang menyebabkan orang lain senang dan merasa aman atas kehadirannya (Sahlan \& Prasetyo, 2012). Maka, untuk mewujudkan kedamaian diperlukan kebudayaan dalam berkata yang baik, bertindak yang baik, serta bersikap yang baik.

\section{Kreatif}

Peristiwa yang menggambarkan nilai karakter kreatif adalah saat kancil dan kura-kura mendapati buah-buahan mereka telah habis dimakan, tetapi pelakunya belum tertangkap. Akhirnya mereka berdua memiliki ide untuk membuat jebakan untuk menangkap pelaku pencuri buah. Karena ide kreatif mereka akhirnya pencuri buah dapat tertangkap. Pencuri buah sendiri adalah monyet yang telah berbohong pada kelinci dan kura-kura. Maka dari kejadian itu pengertian dari nilai kreatif adalah cara atau ide yang digunakan untuk menyelesaikan masalah. Seperti kancil dan kura-kura yang menyelesaikan masalah mengenai pencurian, mereka akhirnya membuat jebakan. Nilai kreatif perlu dikembangkan karena dapat menghasilkan problem solving yang sangat berguna dalam kehidupan. Berikut cuplikan cerita Jebakan Kancil dan Kura-kura yang merepresentasikan nilai karakter.

\footnotetext{
"Kera apakah kamu mencuri buah-buahan kami?" tanya kancil. "e.. tidak kancil” jawab kera sambil ragu. Kancil dan kura-kura membuat jebakan untuk mengetahui siapa pencuri yang telah memakan semua buah milik kancil dan kura-kura. Keesokan harinya Kancil dan kura-kura melihat kera terjebak dijebakan kancil dan kura-kura yang sudah dipasang di dekat sungai.
}

Nilai kreatif menjadi tujuan pendidikan pada masa kini, karena dengan kreativitas siswa lebih mandiri dalam menyelesaikan segala permasalahannya. Kreativitas sendiri memiliki arti yakni menciptakan sesuatu yang baru. Kemampuan kreativitas perlu dikembangkan karena dapat melatih otak dalam berpikir tingkat tinggi. Kesimpulannya bahwa nilai kreatif adalah sikap atau tindakan yang menghasilkan sesuatu yang baru baik dari seni, mesin, pemecahan masalah dan metode-metode yang berbeda (Rachmawati \& Kurniawati, 2005). Nilai kreatif perlu dikembangkan dalam pembelajaran di sekolah karena kemampuan pemecahan masalah akan berguna bagi siswa yang mengerjakan soal-soal dan membutuhkan pemikiran tingkat tinggi. 


\section{PEMBAHASAN}

Melalui kegiatan menganalisis hasil tulisan siswa, terlihat bahwa tulisan mengandung nilai karakter didalamnya. Nilai karakter muncul dalam tulisan siswa, karena hasil cerita siswa berasal dari pemahaman emosional mereka. Kegiatan yang mengaitkan pengungkapan emosional dari hasil kesadaran sensori merupakan bentuk kreativitas. Siswa secara kreatif berpikir untuk menangkap kejadian yang dialami dan dibarengi dengan emosional untuk menilai kejadian itu, hal ini yang mengakibatkan siswa dapat memahami nilai karakter secara tidak sengaja. Kejadian yang diceritakan juga merupakan hasil dari pengalaman siswa sehari-hari dan dari hasil daya imajinasi siswa. Kemampuan siswa menulis secara subjektif berdasarkan imajinasi merupakan kemampuan menulis kreatif (Zhu, Xu, \& Khot, 2009).

Kemampuan siswa dalam menangkap dan memahami peristiwa yang telah dialami perlu adanya kegiatan pengenalan oleh orangtua dan guru. Pengajaran pendidikan karakter membutuhkan komponen pengetahuan, sadar, dan kemauan untuk melakukan tindakan sesuai nilai yang baik (Sudrajad, 2010). Tugas orangtua dan guru untuk memberikan pengetahuan kepada mereka. Guru dapat memberikan pengetahuan mengenai nilai-nilai karakter dengan cara yang menyenangkan agar mudah dipahami siswa, dan siswa tidak merasa bosan. Salah satu kegiatan yang dapat dikenalkan terlebih dahulu adalah dengan bacaan. Cerita yang cocok dikenalkan kepada siswa adalah cerita mengenai penyelesaian masalah dan dari cerita itu siswa menyadari nilai dan pesan yang dapat siswa terapkan dalam kehidupan sehari-harinya (Noor, 2011).

Buku cerita menjadi modal awal dalam membuka wawasan siswa, mengembangkan kognisi dan juga pembentukan sikap. Selain itu, buku bacaan anak harus memuat nilai-nilai yang dapat membuat anak senang berimajinasi, merasa bahwa ikut mengalami sehingga pengalamannya bertambah, pertimbangan moral, serta preferensi sastra dan seni (Thomlinson \& Brown, 2002). Bentuk yang dapat dikembangkan dalam pembelajaran bahasa Indonesia dengan menggunakan cerita anak dengan mengembangkan pemikiran kreatif dan pengetahuannya tentang nilai-nilai kreatif adalah dengan menulis. Menulis cerita, siswa dapat menjelaskan hasil dari pemahamannya terhadap buku yang telah dibaca dengan pengalamannya sehari-hari menjadi sebuah karya cerita yang menghibur dan terdapat nilai didalamnya.

Cerita yang sesuai dengan perkembangan siswa tingkat dasar adalah cerita fiksi yang lebih kepada tokoh binatang yaitu cerita fabel. Manfaat cerita fabel dapat membuat siswa terpesona saat membaca dan melihat tokoh binatang (Tucker, 1991). Gambaran tokoh binatang dalam cerita fabel merupakan preferensi imajinasi dari perilaku tokoh yang disesuaikan dengan pengalaman anak. Cerita fabel penuh dengan pengenalan nilai-nilai moral di dalamnya. Sesuai dengan fungsinya bahwa cerita fabel adalah cerita yang digunakan untuk menanamkan moral kehidupan.

Pembiasaan pembelajaran dengan membaca cerita dan dilanjutkan siswa menulis cerita karya siswa sendiri merupakan upaya guru dalam mengenalkan dan mengarahkan nilai-nilai yang baik dalam kehidupan. Hal ini digunakan untuk memunculkan pendidikan karakter pada saat proses pembelajaran. Pendidikan karakter diperlukan untuk mengajarkan anak menerima aturan yang berguna dan dapat diterima cerita personal, sosial, dan cakupan yang lebih luas yakni institusional (Hurlock, 2008). Maka upaya pembelajaran dan pengenalan pendidikan karakter harus dikerahkan dalam bidang apapun, karena pada usia dasar merupakan usia emas dalam pembentukan karakter dan nilai moral anak.

Cerita karya siswa merepresentasikan kehidupan sehari-harinya. Terlihat dalam alur cerita yang diceritakan, rata-rata adalah cerita tentang persahabatan. Persahabatan diwujudkan dari karakter tokoh yang berteman, saling bercanda, saling berbagi bekal makanan, mengagalkan perilaku mengejek kepada temannya, dan menolong temannya yang dalam kesusahan. Peristiwa itu tersirat dan tersurat dalam cerita fabel karya siswa. Hal itu membuktikan bahwa kegiatan menulis cerita mengajak siswa untuk memikirkan dan menyadari nilai-nilai yang ada saat mereka membangun kehidupan sosialnya. Proses menyadarkan siswa akan nilai-nilai yang selama ini sudah mereka praktikkan dalam lingkungan adalah dasar untuk memberi pengetahuan bahwa ada nilai-nilai karakter yang mereka gunakan dalam kehidupan sehari-hari. Tahapan ini merupakan tahapan operasi formal bagi siswa karena pada tahap ini siswa sudah mampu untuk menyadari dan mampu berpikir abstrak dan lebih menyukai kisah cerita yang menampilkan masalah serta membawa mereka untuk mencari penyelesaiannya (Nurgiyantoro, 2010). Karya cerita siswa menjelaskan kehidupan pertemanan untuk terbangun dan sampai pada akhirnya terjadi masalah dalam pertemanan tersebut, kemudian siswa menceritakan bagaimana penyelesaian masalah yang terjadi dalam kehidupannya.

Pendidikan karakter dengan memanfaatkan buku cerita dan keterampilan menulis dapat mengembangkan potensi berpikir anak mengenai nilai-nilai karakter dalam kehidupannya. Nilai-nilai karakter sangat berguna dalam membentuk pribadi yang bermoral. Pada zaman yang mudah dalam masuknya budaya luar dan sangat mudah anak-anak bangsa untuk terseret dan menyesuaikan nilai-nilai moral yang dianutnya. Maka, peran guru, orangtua dan seluruh aspek masyarakat mempunyai andil penting dalam mengarahkan dan ikut membangun nilai-nilai karakter anak bangsa dengan cara apapun.

\section{SIMPULAN}

Menulis kreatif merupakan pembelajaran bahasa Indonesia yang mengembangkan keterampilan berpikir dengan mengaitkan imajinasinya dan kehidupan sehari-harinya. Perlu latihan dan pengetahuan mengenai cerita anak dalam menulis cerita. Anak-anak perlu diberikan bacaan/cerita fiksi/fabel yang dapat menumbuhkan minat dan wawasan mengenai isi cerita tersebut. Bacaan anak-anak sarat akan nilai-nilai moral yang diajarkan. Berbantuan gambar dalam buku bacaan sebagai media yang mengaktifkan imajinasi anak dan mengkonkretkan peristiwa yang diceritakan. 
Menulis salah satu bentuk produktif berupa tindakan menulis untuk meluapkan isi pengetahuan anak dalam bentuk tulisan. Melalui kegiatan menulis, dapat diketahui pemahaman siswa akan nilai-nilai yang telah diajarkan dalam buku bacaan sudah dipahami atau tidak. Maka, pendidikan karakter melalui pembelajaran bahasa Indonesia dapat dikenalkan dengan media dan cara yang menyenangkan. Membutuhkan strategi menulis yang lebih bervariatif yang dapat diajarkan kepada siswa. Mengingat keterampilan menulis adalah keterampilan yang cukup susah bagi siswa karena memadukan kemampuan berpikir dengan pengungkapannya lewat tulisan. Sehingga, guru masih membutuhkan strategi-strategi lain yang memudahkan siswa dan bervariasi untuk memudahkan pembelajaran menulis cerita.

\section{DAFTAR RUJUKAN}

Asriani, P., Sa'dijah., \& Akbar, S. (2017). Bahan Ajar Berbasis Pendidikan Karakter uzalntuk. Jurnal Pendidikan: Teori, Penelitian, dan Pengembangan, 2(11), 1456-1468.

Badan Standar Nasional. (2010). Paradigma Pendidikan Nasional di Abad 21. Jakarta: BSNP.

Erlfindri, dkk. (2012). Pendidikan Karakter, Kerangka, Metode dan Aplikasi untuk Pendidikan dan Profesional. Jakarta: Baduose Media.

Fathurrohman, P. (2013). Pengembangan Pendidikan Karakter. Bandung: PT. Refika Aditama.

Hoge, J. D. (2002). Character Education, Citizenship Education, and the Social Studies AU - Hoge, John Douglas. The Social Studies, 93(3), 103-108. https://doi.org/10.1080/00377990209599891

Hurlock, E. B. (2008). Perkembangan Anak (Terjemahan dari Med. Meitasari Tjandrasa \& Muslichah Zarkasi). Jakarta: Erlangga.

Kaelan. (2008). Pendidikan Pancasila. Yogyakarta: Paradigma.

Kette, E. S. S., Pratiwi, Y., \& Sunoto, S. (2016). Pengembangan Bahan Pelatihan Menulis Cerita Pendek Bermuatan Nilai Karakter untuk Guru SMP Negeri Mata Pelajaran Bahasa Indonesia Se-Kota Kupang. Jurnal Pendidikan: Teori, Penelitian, dan Pengembangan, 1(4), 698-704.

Kusmayadi., Suyitno, I., \& Maryaeni. (2017). Pengembangan Multimedia Cerita Rakyat. Jurnal Pendidikan: Teori, Penelitian, dan Pengembangan, 2(7), 902-909.

Moleong, J. L. (2016). Metodologi Penelitian Kualitatif. Bandung: PT. Remaja Rosdakarya.

Narwanti, S. (2012). Pendidikan Karakter: Pengintegrasian 18 Nilai Pembentuk Karakter dalam Mata Pelajaran. Jakarta: Familia.

Nielsen, T. W. (2003). Rudolf Steiner's Pedagogy of Imagination: A Phenomenological Case Study. International Conference on Imagination in Education, 29.

Noor, R. M. (2011). Pendidikan Karakter Berbasis Sastra. Yogyakarta: Ar-Ruzz Media.

Nurgiyantoro. (2010a). Sastra Anak: Pengantar Pemahaman Dunia Anak. Yogyakarta: Gadjah Mada University Press.

Nurgiyantoro. (2010b). Sastra Anak:Pengantar Pemahaman Dunia Anak. Yogyakarta: Gajah Mada University Press.

Rachmawati, Y., \& Kurniawati, E. (2005). Strategi Pengembangan Kreativitas Pada Anak Usia Taman Kanak-kanak. Jakarta: Depdiknas.

Rahayu, E. (2016). Peningkatan Kemampuan Menulis Kreatif Siswa Melalui Strategi Rekayasa Teks. Jurnal Pendidikan, 27, 345-355. https://doi.org/https://doi.org/10.24114/bhs.v27i4.5706

Rehusisma, L. A., Indriwati, S. E., \& Suarsini, E. (2017). Pengembangan Media Pembelajaran Booklet dan Video sebagai Penguatan Karakter Hidup Bersih dan Sehat. Jurnal Pendidikan: Teori, Penelitian, dan Pengembangan, 2(9), $1238-1243$.

Ridwan, M. H., \& Mudiono, A. (2017). Analisis Muatan Nilai-Nilai Karakter pada Buku Siswa Kelas IV Sekolah Dasar Tema Indahnya Kebersamaan. Jurnal Wahana Sekolah Dasar, 25(1), 1-7.

Sahlan, A., \& Prasetyo, A. T. (2012). Konsep dan Model Pendidikan Karakter. Yogyakarta: Ar-Ruzz Media.

Sudrajad, A. (2010). Pendidikan Karakter. Retrieved from http://akhmadsudrajat.wordpress.com/2010/08/20/pendidikankarakter-di-mp/

Suyadi. (2013). Strategi Pembelajaran Pendidikan Karakter. Bandung: PT. Remaja Rosdakarya.

Thomlinson, C., \& Brown, C. (2002). Essential's of Children's Literature. Boston: Pearson Education Company.

Tucker, N. (1991). The Children Book: A Psychological and Literaly Exploration. New York: Cambridge University Press.

Wachidah, L. R., Suwignyo, H., \& Widiati, N. (2017). Rakyat Sebagai Bahan Bacaan Literasi Moral. Jurnal Pendidikan: Teori, Penelitian, dan Pengembangan, 2(7), 894-901.

Wulananda, R., Saryono, D., \& Suwignyo, H. (2016). Tersedia secara online EISSN: 2502-471X Estetika Profetik Novel Muhammad: Lelaki Penggenggam Hujan Karya Tasaro G. K. sebagai Sumber Pendidikan Karakter. Jurnal Pendidikan: Teori, Penelitian, dan Pengembangan, 1(7), 1350-1363.

Zhu, X., Xu, Z., \& Khot, T. (2009). How creative is your writing? A linguistic creativity measure from computer science and cognitive psychology perspectives. Proc. of the Workshop on Computational Approaches to Linguistic Creativity CALC '09, (June), 87-93. https://doi.org/10.3115/1642011.1642023 